\title{
Natural and Anthropic Soil Acidification in the West of Romania
}

\begin{abstract}
LUCIAN NITA', ADIA GROZAV² , GHEORGHE ROGOBETE ${ }^{2}$
${ }^{1}$ Banat University of Agricultural Sciences and Veterinary Medicine King Michael I of Romania from Timisoara, 119 Calea Aradului, 300645, Timisoara, Romania

2Politehnica University Timisoara, Faculty of Civil Engineering, George Enescu, 300022, Timisoara, Romania

Acidification means the increase in soil acidity due to the natural soil - forming process, frequently in the warm and cool temperate zones, on a wide range of acid rocks consisting of $\tilde{A} 60 \% \mathrm{SiO}_{2}$, primarily as silicate minerals. Typical acid rocks are granites, granodiorites and rhyolites. Subject to intense weathering processes, destruction of clays rich in aluminum occurs in these soils, giving acid conditions. Anthropic acidification consists in the increase in soil acidity due to the action of acid rains or to various farming techniques application of acid - forming fertilizers.
\end{abstract}

Keywords: soil, acidity, acidification, acid rain, fertilizer, liming

In accordance with USDA-Soil Taxonomy, soil is a natural corps composed of solid, liquid and gaseous phases, which appears on the Earth's crust and presents horizons or layers, distinct of the primary material, or which has the capability to support plants [1].

Soil genesis can be regarded as a translocation process of inorganic and organic substances, vertical and lateral in wet climates, and from bottom to top in arid climates.

The translocation and precipitation of weathering complex is conditioned by the nature of mineral parent material, and by the organic acids (fulvic, humic, polyuronic, amino-acids, etc.) [2] .

The major pedogenesis processes are: bioaccumulation, eluviation-illuviation, ferrolyse, gleysation, salinization- sodication, lateritization, plinthization and uniformization [3].

The existence and their intensity are dependent on the climate, relief, vegetation and parent material, and time.

Romanian territory can be characterized by an udic moisture regime-annual average precipitations exceed evapo-transpiration, and a mesic temperature regime, with $8^{\circ} \mathrm{C}$ up to $15^{\circ} \mathrm{C}$ of about $2 / 3$ from total area.

In these climatic conditions it develops a vegetation zonality, with forest steppe in the plain and foresthill-forest mountain, which has an acid character, and consequently will form acid soils.

Soil-forming process takes place slowly and gradually, the parent material is affected by biological and chemical weathering, the soluble salts (chlorides, sulfates, carbonates) are transported in the depth, the compounds of $\mathrm{Fe}^{3+}$ and $\mathrm{Mn}^{4+}$ released from silicates, and the clay particles from the weathering complex, will be formed $B$ weathering complex in a Bt horizon. The phenomenon is enhanced by fulvic acids and Fe - chelates in the Alpine zones, where the clay-humus complexes are degraded with a new horizon formed - B spodic.

This type of pedogenesis leads to acid soils formation. It can be concluded that there is a natural acidification above which an anthropic acidification was added in the last hundred years.

In the soil Science the expression for acidity is:

-active acidity or soil reaction, which consists in the activity of the hydronium ion from soil solution (1/2.5 soil water), respectively $\mathrm{pH}$. Frequently, the $\mathrm{pH}$ can be: acid: very strong acid < 4.3; strong acid 4.3-5.0; acid 5.0-5.8, weak acid 5.8-6.8; neutral: 6.8-7.2; alkaline: weak alkaline 7.2-8.4; alkaline 8.4-9.0; strong alkaline $\geq 9.1$.

Within land improvement, acid soils are regarded as those with $\mathrm{pH} \leq 5.8$.

-titrable acidity:

-determined through percolation with $\mathrm{KCl}$ in for releasing the exchangeable cations from the adsorbtion complex $\left(\mathrm{H}^{+}\right.$and $\left.\mathrm{Al}^{3+}\right)=$ exchange acidity,

- determined through percolation with acetate of $\mathrm{Na}, \mathrm{K}$, $\mathrm{Ca}, \mathrm{NH}_{4}$, which increase $\mathrm{pH}$ of 8.3 and release the exchangeable cations from the adsorption complex, but also $\mathrm{H}^{+}$and $\mathrm{Al} \mathrm{I}^{3+}$ unchangeable in natural conditions = total acidity, or hydrolytic acidity [4].

The soil, the plants and the atmosphere are all components of a dynamic system in which water and substances flow along potential gradients, from a position where the water potential is high to one where is low. The transport of water across cell membranes is predominantly the result of a negative water potential gradient and the transport of solutes predominantly along a positive solute potential gradient.

The root system of a plant can be with a total length of several $\mathrm{km}$; but less than $1 \%$ of the surface soil particles come into direct contact with the surface area of the roots.

Uptake and adsorption of the nutrient ions are a contact exchange in which the plant roots release $\mathrm{H}^{+}$and $\mathrm{HCO}_{3}^{-}$ uptake cations and anions for their metabolism. When the soil is acidic with $\mathrm{H}^{+}$and $\mathrm{Al}^{3+}$ in quantity in the soil solution, the root hair can't release $\mathrm{H}^{+}$and , and the nutrition process is blocked.

Acidification affects the transformation of silicates and release in the soil solution when the $\mathrm{pH}$ has decreased to $\mathrm{pH} \mathrm{5}$, because the SiO-Al become protonated. Acidity moves down the soil profile and $\mathrm{Al}^{3+}$ covers the clay surfaces, blocking adsorption basic cations. $\mathrm{Al}^{3+}$ in the soil solution is toxic for major plants; toxicity enhanced due to $\mathrm{Fe}^{2+}$ and $\mathrm{Mn}^{2+}$ accumulation [5].

In the case of nonaerated soils with an argic horizon, the main process is ferrolysis, with a ferrolytic breakdown of clay minerals. In these conditions:

$$
\mathrm{Fe}(\mathrm{OH})_{3} \stackrel{\mathrm{CO}_{2}}{\longrightarrow} \mathrm{Fe}\left(\mathrm{HCO}_{3}\right)_{2}
$$

The $\mathrm{Fe}^{2+}$ ions occupy a significant fraction of exchange sites on the soil colloids, $\mathrm{Fe}^{2+}$ oxidizes in the dry period and generates acidity. 
Clay migration from the surface and the ferrolysis process lead to an argic horizon in the subsoil. Mobilization occurs by detachment of clay from soil aggregates as wetting reduces the ionic concentration and the forces holding the clays together. Clay is transported in suspension down cracks and pores. Downward percolation of moisture is slow leading to the development of stagnic properties in the lower part of the albic horizon. This also provides the reduction conditions which favor the ferrolytic breakdown of clay minerals.

The impervious horizon has adverse effects upon plants. The negative effects of acidity can be illustrated on the agricultural production (\%) related on the optimal values.

\begin{tabular}{|c|c|c|c|c|c|}
\hline \multirow[t]{2}{*}{ Crop } & \multicolumn{4}{|c|}{$\mathrm{pH}$} & \multirow{8}{*}{$\begin{array}{c}\text { Table } 1 \\
\text { RELATIVE } \\
\text { PRODUCTIONSAT pH [4] }\end{array}$} \\
\hline & 4.7 & 5.8 & 6.8 & 7.5 & \\
\hline maize & 34 & 83 & 100 & 85 & \\
\hline wheat & 68 & 83 & 100 & 99 & \\
\hline barley & 0 & 80 & 95 & 100 & \\
\hline alfaalfa & 2 & 42 & 100 & 100 & \\
\hline trefoil & 12 & 53 & 98 & 100 & \\
\hline soya & 65 & 80 & 100 & 93 & \\
\hline
\end{tabular}

The natural acidification process can be augmented by the anthropic acidification, produced in the natural ecosystems by industrial works, and in the cultivated ecosystems by fertilization with chemical fertilizer, and also with pollutants from acid rains.

\section{Experimental part}

Materials and methods

The presentation of the acid soil problems, and of the natural and anthropic acidification and their extension in the south-west of Romania is based on the pedological reports realized by the authors of this paper and also by the scientific cooperation with specialized institutions on soil study and soil improvement.

A soil and cadastral survey realized with the Office for Pedological and Agrochemical (OSPA) Timis, Institute for Pedological and Agrochemical Research (ICPA) Bucharest, Institute for Irrigation and Drainage (ICTID) BaneasaGiurgiu can also be quoted.

Disturbed and undisturbed samples from hundreds of soil profiles were physically and chemically analyzed in the laboratory in accordance with standards in operation.

The scientific research for acid soils improvement was effectuated in field experiments. In these field experiments there were settled variants for researching agricultural cultures with a different application for fertilizer rates, for liming material and for improvement of the air and water regime.

Field experiments are localized in the Banat-Lovrin, Sanandrei, Dumbrava, Sudrias, Gavojdia regions.

\section{Results and discussions}

According to soil forming processes, the studied thematic can be grouped as follows:

a) natural acidification, illustrated by the acid soils forming process in Banat, and the extension of the area with acid soils in the world, in Romania, and in the Banat region;

b)anthropic acidification, result of application of fertilizer and because of acid rains;

c) liming and soil improvement.

a) The most significant proton $\left(\mathrm{H}^{+}\right)$generation in soil is associated with the $\mathrm{C}, \mathrm{N}$, and $\mathrm{S}$ cycle [6].
In the solid phase of the soil, proton donors are:

- cations forming weak hydroxides (Al, $\mathrm{Fe}, \mathrm{Mn}$ )

$$
\mathrm{Al}^{3+}+\mathrm{H}_{2} \mathrm{O} \rightarrow \mathrm{AlOH}^{2+}+\mathrm{H}^{+}
$$

In fact, $\mathrm{Al}$ is a hexahydronium $\left.\left[\mathrm{Al}(\mathrm{OH})_{2}\right)_{6}\right]^{3+}$, in the shape of which contains exchangeable protons:

$$
\left[\mathrm{Al}\left(\mathrm{OH}_{2}\right)_{6}\right]^{3+}+\mathrm{H}_{2} \mathrm{O} \rightarrow\left[\mathrm{Al}(\mathrm{OH})\left(\mathrm{OH}_{2}\right)_{5}\right]^{2+}+\mathrm{H}_{2} \mathrm{O}^{+}
$$

-nitrification of organic matter:

$$
\begin{gathered}
\mathrm{R}-\mathrm{C}-\mathrm{NH}_{2} \rightarrow \mathrm{NH}_{3}+\mathrm{H}^{+} \rightarrow \mathrm{NH}_{4}^{+}+ \\
+2 \mathrm{O}_{2} \rightarrow \mathrm{NO}_{3}^{-}+2 \mathrm{H}^{+}+\mathrm{H}_{2} \mathrm{O}
\end{gathered}
$$

In the liquid phase (example):

$$
\begin{gathered}
\mathrm{HCO}_{3}^{-}+\mathrm{H}^{+} ; \mathrm{NH}_{4}^{+} \rightarrow \mathrm{N}_{\text {organic }}+\mathrm{H}^{+} \\
\mathrm{R}-\mathrm{CH}_{2} \mathrm{OH}+\mathrm{CO}_{2} \rightarrow \mathrm{RCOO}^{-}+\mathrm{H}_{2} \mathrm{O}+\mathrm{H}^{+}
\end{gathered}
$$

In the acid soils, $\mathrm{CO}_{2}$ is replaced by fulvic acid and crenic acid, under conifers and mountain meadow [7].

The extension of acid soils in the world; presented in table 2, is quoted after the World Reference Base for soil Resources - Atlas [8].

The greatest areas with strong acid soils belong to Acrisoils ( 1 billion ha) with pH 3.7-4.2, Alisoils ( 100 hundred ha) with $\mathrm{pH}$ 3.2-3.3, developed in tropical, subtropical and warm temperate regions, on acid rocks with strong weathered clays, in Southeast Asia and USA, the Amazon basin and in both East and West Africa (table 2).

In the category of strong acid soils are also Ferralsoils (750 mill. ha), in tropical regions, mainly South and Central America and Central Africa.

Cambisoils occur worldwide, with a dominance in the temperate regions, they are one of the most widespread soils, covering 1.5 billion hectares, but only Dystric Cambisoils are strongly acidic. Worldwide, from the total of 15 billion ha, the acid soils occupies $40 \%$.

In Romania, with a total area of 23 million ha, the acid soils represent about $47 \%$ (table 3) [9].

Strong acid soils, which are most common in mountainous areas are: Umbrisoils, Dystric Cambisoils, Alosoils, Podzols.

The hilly zone has as acid soils Luvisoils and Planosoils, with the biggest agricultural land use which needs soil improvement.

The situation of acid soils in the counties of Caras Severin and Timis as presented in table 4.

Most extensive soil types are Luvisoils, with 294.565 hectares, in the hilly zone, with agricultural use land and a pH between 5 and 6 (moderate acid).

\section{b)Anthropic acidification}

- A prolonged application of chemical fertilizers with reaction physiological acid, like Ammonium sulfate, Ammonium chloride, Ammonium nitrate, has been the result of a great acidification for soils with a $\mathrm{pH}$ of 7.5-8.0. Such, Chernozems from Lovrin (Timis) area, one of the most fertile soils from the world, have now [10]: $\mathrm{cm})$;

- profile no.20 - Lovrin : $5.80(0-22 \mathrm{~cm}) ; 5.95$ (22-38

$$
\text { - profile no.21 - Lovrin : } 6.29(0-18 \mathrm{~cm}) ; 6.33 \text { (18-32 }
$$
$\mathrm{cm})$;

- profile no.1 - Arad: $5.70(0-30 \mathrm{~cm}) ; 5.92(30-65 \mathrm{~cm})$.

It is estimated that the $\mathrm{pH}$ decrease with one unit of measure for: 


\begin{tabular}{|l|c|c|c|}
\hline Reference Soil Groups & $\begin{array}{l}\text { Area } \\
\text { million ha. }\end{array}$ & $\begin{array}{c}\text { Acidity } \\
p H_{H_{2} \mathrm{O}}\end{array}$ & $\begin{array}{l}\text { Base saturation } \\
\%\end{array}$ \\
\hline Acrisols & 1000 & $3.7-5.0$ & $<50$ \\
\hline Alisols & 100 & $3.3-3.5$ & $1-25$ \\
\hline Andosols & 110 & $4.6-5.9$ & $<50$ \\
\hline Cambisols & 1500 & $5.1-6.7$ & $<50$ \\
\hline Ferralsols & 750 & $3.9-4.3$ & $2-20$ \\
\hline Fluvisols & 350 & $3.9-6.6$ & $20-60$ \\
\hline Histosols & 325 & $5.0-7.0$ & $\sim 50$ \\
\hline Luvisols & 600 & $6.0-8.0$ & $50-75$ \\
\hline Planosols & 130 & $5.4-6.7$ & $<50$ \\
\hline Plinthosols & 60 & $5.9-6.6$ & $<50$ \\
\hline Podzols & 485 & $3.5-5.0$ & $<50$ \\
\hline Retisols & 320 & $4.2-5.2$ & $<50$ \\
\hline Stagnosols & 200 & $5.0-6.0$ & $\sim 50$ \\
\hline Umbrisols & 100 & $5.5-6.1$ & $<50$ \\
\hline Total & & 6.030 & \\
\hline $\begin{array}{l}\text { Total world soils resources } \\
\text { Acid soils represents: } 40.14 \%\end{array}$ & & \\
\hline
\end{tabular}

Table 3

ACID SOILS IN ROMANIA

\begin{tabular}{|l|l|l|l|}
\hline Soil types & WRB 2014 & $\begin{array}{l}\text { Area } \\
\text { thousand } \\
\text { ha }\end{array}$ & $\begin{array}{l}\text { Acidity } \\
p H_{\mathrm{H}_{2} \mathrm{O}}\end{array}$ \\
\hline Aluviosol & Fluvisol & 180 & $5.0-7.5$ \\
\hline Nigrosol & Umbrisol & 5 & $4.0-5.0$ \\
\hline Humosiosol & Umbrisol & 15 & $3.5-4.5$ \\
\hline Districambosol & Cambisol & 3220 & $5.0-5.5$ \\
\hline Preluvosol & Luvisol & 1180 & $5.5-6.8$ \\
\hline Luvosol & Luvisol & 4875 & $5.0-5.8$ \\
\hline Planosol & Planosol & 5 & $5.2-6.8$ \\
\hline Prepodzol & Podzol & 960 & $4.2-5.2$ \\
\hline Podzol & Podzol & 270 & $3.6-4.6$ \\
\hline Andosol & Andosol & 180 & $4.4-5.1$ \\
\hline Stagnosol & Stagnosol & 100 & $5.4-6.4$ \\
\hline Histosol & Histosol & 265 & $3.6-6.8$ \\
\hline $\begin{array}{l}\text { Total 11.255 } \\
\text { Romania, total soils 23.839 } \\
\text { Acid soils represents: } 47.21 \%\end{array}$ & \\
\hline
\end{tabular}

-Ammonium sulfate, in about 8 years;

-Urea, in about 25 years;

-Superphosphate, in about 45 years.

Drainage of acid - sulfate soils

In many deltaic areas and other regions bordering coasts, sometimes in river valleys as well, the drainage provokes a strong acidification, after soil organic materials and elemental sulfur are oxidized

$$
\begin{gathered}
2 \mathrm{~S}+2 \mathrm{H}_{2} \mathrm{O}+3 \mathrm{O}_{2} \rightarrow 2 \mathrm{H}_{2} \mathrm{SO}_{4} \\
4 \mathrm{FeS}+6 \mathrm{H}_{2} \mathrm{O}+3 \mathrm{O}_{2} \rightarrow 4 \mathrm{~S}+4 \mathrm{Fe}(\mathrm{OH})_{3}
\end{gathered}
$$

Table 2

WORLD WIDE ACID SOILS - WRB 2014

Table 4

ACID SOILS IN CARAS-SEVERIN AND TIMIS COUNTIES

\begin{tabular}{|l|l|l|l|l|}
\hline Soil types & WRB 2014 & \multicolumn{2}{l|}{ Area, } & \multirow{2}{*}{ Total } \\
\cline { 3 - 4 } & & & \multicolumn{2}{l}{} \\
\cline { 3 - 4 } & & CS & TM & \\
\hline Aluviosol & Fluvisol & 28573 & 29150 & 57723 \\
\hline Nigrosol & Umbrisol & 799 & - & 799 \\
\hline Humosiosol & Umbrisol & 26055 & - & 26055 \\
\hline Districambosol & Cambisol & 40122 & - & 40122 \\
\hline Preluviosol & Luvisol & 41840 & 85131 & 126971 \\
\hline Luvosol & Luvisol & 91033 & 76561 & 167594 \\
\hline Planosol & Planosol & 559 & 4214 & 4773 \\
\hline Prepodzol & Podzol & 320 & - & 320 \\
\hline Podzol & Podzol & 799 & - & 799 \\
\hline Stagnosol & Stagnosol & 4396 & 737 & 11771 \\
\hline Histosol & Histosol & 240 & - & 240 \\
\hline Total acid soils, ha & 234736 & 202431 & 437167 \\
\hline Total soils, ha & & 399620 & 702398 & 1.102 .018 \\
\hline Acid soils \% & & 53.74 & 28.82 & 41.28 \\
\hline
\end{tabular}

In the absence of carbonates:

$$
\begin{aligned}
& 2 \mathrm{Fe}(\mathrm{OH})_{3}+3 \mathrm{H}_{2} \mathrm{SO}_{4} \rightarrow \mathrm{Fe}_{2}\left(\mathrm{SO}_{4}\right)_{3}+6 \mathrm{H}_{2} \mathrm{O} \\
& 2 \mathrm{Al}(\mathrm{OH})_{3}+3 \mathrm{H}_{2} \mathrm{SO}_{4} \rightarrow \mathrm{Al}_{2}\left(\mathrm{SO}_{4}\right)_{3}+6 \mathrm{H}_{2} \mathrm{O}
\end{aligned}
$$

Aluminum and iron sulfates hydrolyse gradually in the first years, and the $\mathrm{pH}$ decreases to $\mathrm{pH}$ 2-3.

$$
\mathrm{Fe}_{2}\left(\mathrm{SO}_{4}\right)_{3}+2 \mathrm{H}_{2} \mathrm{O} \rightarrow 2 \mathrm{Fe}(\mathrm{OH}) \mathrm{SO}_{4}+\mathrm{H}_{2} \mathrm{SO}_{4}
$$

\section{Acid rain}

Rain is with a $p H$ of $5.0-5.5$, but the value can increase 10 - 100 times over natural $\mathrm{pH}$ because of the presence in the atmosphere of the primary and secondary pollutants created from industrial and domestic activities as: $\mathrm{SO}_{2}$ $\mathrm{NO}, \mathrm{NO}_{x^{\prime}} \mathrm{N}_{2} \mathrm{O}, \mathrm{NH}_{3}, \mathrm{CO}_{2}$, hydrocarbons and secondary 
pollutants like $\mathrm{O}_{3^{\prime}} \mathrm{HNO}_{3^{\prime}}$ fuel ash, metallic particles and so on [11].

The burning of the coals in the Thermo-electric power plants, and furnaces, the burning of the fuels in the vehicles or the degradation of the fertilizers in the soil by denitrification, represents the primary source for the atmospheric pollutants.

$$
\begin{gathered}
4 \mathrm{FeS}_{2}+11 \mathrm{O}_{2} \rightarrow 2 \mathrm{Fe}_{2} \mathrm{O}_{3}+8 \mathrm{SO}_{2} \\
\mathrm{NO}_{3} \rightarrow \mathrm{NO}_{2} \rightarrow \mathrm{NO}
\end{gathered}
$$

The ecosystems acidification can be also generated by nitrification

$$
\mathrm{NH}_{4}^{+}+2 \mathrm{O}_{2} \rightarrow \mathrm{NO}_{3}+\mathrm{H}_{2} \mathrm{O}+2 \mathrm{H}^{+}
$$

The major oxidants for the production of dissociate $\mathrm{SO}_{4}{ }^{2-}$ and $\mathrm{H}^{+}$ions are $\mathrm{H}_{2} \mathrm{O}_{2}$ and $\mathrm{O}_{3}$.

\section{c) Liming and soil improvement}

Acid soils improvement needs in the first place to decrease the acidity by liming and also to improve the air and water regime. Additionally fertilization with physiological alkaline fertilizer is also necessary.

Liming is recommended on the soils with $\mathrm{pH}<5.8$ and exchangeable - cation percentage $\mathrm{V}<75$.

In the presence exchangeable aluminium in quantities $>0.2-0.3 \mathrm{me} / 100 \mathrm{~g}$ sol, limming is recommended even the $\mathrm{pH}$ is greater than 5.8.

In fact, the amendament rate is calculated with formula:

$$
\mathrm{CaCO}_{3} \frac{t}{h a}=S B_{i}\left(\frac{V_{d}}{V_{i}}-1\right) \cdot H \cdot 0.06 \frac{100}{P N A}
$$

in which:

SBi - initial total exchangeable bases;

$\mathrm{Vd}$ - degree of base saturation wanted (70-100\%);

$\mathrm{Vi}$ - initial degree of base saturation;

$\mathrm{H}$ - depth of soil layer $(25 \mathrm{~cm}$ for field culture, $10 \mathrm{~cm}$ for meadow);

0.06 - for tone/ha;

PNA - neutralizing power of amendment (limestone $=$ 90; marl $=15$; sugar lime $=50$; Thomas slag $=95$; dolomite $=85$; burntlime = 178). Amendment application will be realized uniformly by tillage.

Because of Ca leaching, after 8 - 10 years it is necessary to apply less than half of the initially dose (about $4-5 \mathrm{t} / \mathrm{ha}$ ).

\section{Conclusions}

Soil acidity and anthropic acidification are regarded as degradation and environment pollution because they generate multitudinous unfavorable effects for human society and the environment.

Acid soils, constituted by natural soil - forming factors, from the total areas of 15 billion hectares land in use in the world, represents about 6 billion ha (about $40 \%$ ).

The production capacity in the case of strong-moderate acidity soils is considerably decreased by $34-68 \%$ in comparison with soils with neutral $\mathrm{pH}$.

Natural acidification generates also $\mathrm{Al}^{3+}$ toxic for plants and for rivers.

Anthropic acidification produced by the primary and secondary pollutants which arrived in the soil with acid rain, affected the quantity and quality of the agricultural products.

The land with acid soils must be improved with liming material and for anthropic acidification a vast program for pollution control is necessary.

\section{References}

1.*** Survey Staff. Soil Taxonomy, Agric. Handbook, 436, USDA, 1999, p. 869;

2.ROGOBETE GH., GROZAV A., Soil Science, Editura Politehnica, Timisoara, 2016, p.223-237;

3.ROGOBETE GH., GROZAV A., BEUTURA D., NEMES I., Pedogenic factors and processes in the temperate zone, vol. VI, 2007, p.67-74;

4.TARAU D., ROGOBETE GH., DICU D., The soils from western of Romania, Editura Eurobit, Timi'oara, 2016, p. 346-354;

5.FLOREA N., Degradation, protection and land improvement, Editura Bucuresti, 2003, 106-109, p.201-205;

6.BLAKE L., Rothamsted Research, Harpenden UK, Encyclopedia of soils, 1, Elsevier Ltd, 2005, p.1-11;

7.BOLAN, N. S., CURTIN D., ADRIANO D. C., Encyclopedia of Soils, 1, Elsevier Ltd, 2005,p. 11-16;

8.*** I.U.S.S., Working Group, W.R.B, World Soil Resources, No. 106, 2014, F.A.O., Rome;

9.FLOREA N., MUNTEANU I., cordon., The Romanian Soil Taxonomy System, Editura SITECH, Craiova, 2012, p.206;

10.*** National Symposium of Pedology, 1995, Timisoara;

11.SCHNITZER M., Encyclopedia of Soils, Elsevier, No.2, 2005, p. 8593.

Manuscript received:21.11.2018 